\title{
Mysticism and the Psychology of Christian Religious Experience
}

\author{
Juvénal Balisasa \\ Valley View University, Adentan-Accra, Ghana; Andrews University, MI, USA
}

\begin{abstract}
The understanding and use of the term mysticism pose a growing challenge in world religions in general, and in Christina in particular. While some Christian denominations easily identify with the concept and practices of mysticism, others approach it at best with skepticism, as they relate it more to eastern religions than Christian traditions. Most especially, traditional Catholicism with its allies easily reckons with a long-lasting mystical tradition, while radical evangelicalism shuns mysticism both conceptually and practically. However, a closer look at the popular definitions and understandings of the term reveals that mysticism is more widely practiced than generally known. This paper compares and contrasts the basic understandings and interpretations of mysticism within the Christendom and weighs them against related biblical principle in order to find out whether mysticism provides safe Christian religious experiences or not. The paper ends with a brief focus on a specific Christian religious group that rejects all forms of mysticism but some religious thinkers ironically brand it, sometimes, as a cult and mystical group. The paper aims at winning the Christians' attention to the kind of spiritual damage the concept and practices of mysticism are causing to believers through either mere propositional truth exposition or syncretic innovations in the Christian church.
\end{abstract}

Keywords: mysticism, mystics, Romanism, protestantism, Seventh-Day Adventist, religious experience, psychology of religious experience

\section{Introduction}

Reading critically through the literature on mysticism, one is compelled to be very careful in concluding the meanings and interpretations of statements about the concept.

This is especially true when one considers, on one hand, the fact that some writers such as Chafer (1976) identified two types of mysticism, that is, false mysticism and true mysticism; and, on the other hand, others like Johnston (2003) highlighted the difficulty in defining the word "mysticism".

For Chafer (1976, p. 12), false mysticism is: The theory that divine revelation is not limited to the written word of God, but that God bestows added truth to souls that are sufficiently quickened by the spirit of God to receive it.

With regard to "true" mysticism, Chafer (1976, p.14) asserted that:

It contends that all believers are indwelt by the spirit and thus are in a position to be enlightened directly by Him, but that there is one complete revelation given, and that the illuminating work of the spirit will be confined to the unveiling of

Juvénal Balisasa, Ph.D. candidate, lectures, Valley View University; a religious education doctoral at Andrews University. 
the scriptures to the mind and the heart.

Concerning the difficulty in defining mysticism, Johnston (1997) remarked that it is far from easy to define the word "mysticism". To underscore this important observation, Johnson (1997, p. 15) continued saying,

Writing at the end of the last century William Ralph Inge cited no less than 26 different definitions of this word; and he could cite 50 or a 100, if he was writing today. For he would find himself involved with Zen, challenged by Dr. D. T. Suzuki, poring over books on yoga, contending with Thomas Melton, Mahatma Gandhi, and the Miharishi Mahesh Yogi. Moreover, he would have to deal with cosmic consciousness, with sudden illumination, with the occult, and even with witchcraft. And he might well throw up agonized hands in despair.

With such cautions at hand, a non-expert reader of mysticism begins to wonder whether the literature on this concept at hand is really worth reading!

This paper will attempt to provide a balanced cross section of literature on the topic taking into account the two views expressed by Chafer that will be considered as the two extremes of the definition domain of mysticism in this paper.

The paper will, however, select most materials that tend to address mysticism in the Christian religious experience which is the focus of the topic.

Whether mysticism can be easily defined or not, whether there are false and true mysticisms will not be a stumbling block to the literature survey, but rather an opportunity to provide an easy and helpful guide for someone who is unfamiliar with the area.

\section{Statement of the Problem}

The term "mysticism" has often appeared to the casual inquirer which is associated with the Eastern religions such as Hinduism and Buddhism. However, as mystical experiences are found in virtually all religious groupings, it may not be right to attribute this concept to specific religions or cultures. It is even better to talk of Buddhist mysticism, Islamic mysticism, Christian mysticism, and even the Western mysticism, African tradition religions' mysticism, etc..

The issue that the paper seeks to explore is the basic meaning of mysticism and its reality in the Christian religious experience.

\section{The Purpose of the Paper}

The purpose of this paper is threefold:

(1) Firstly, the study will establish the etymology, the origin, and the common use of the concept of mysticism.

(2) Secondly, it will trace the historical development of mysticism in the Christian church;

(3) Finally, it will highlight the relevance of mystical practices or experiences to religious experience with particular emphasis on seventh-day Adventism.

\section{Definition(s) of Mysticism}

As mentioned earlier, some writers, such as Johnston (1997), on the subject of mysticism, seemed to understand the exact definition of this term, which is not a straightforward exercise. However, the numerous definitions that have been suggested by experts of this concept are informative enough to bring to mind what it 
is all about. The following is a few definitions that have been selected to guide the survey of this paper.

Soelle (2001) in her popular book, The Silent Cry: Mysticism and Resistance, stated that:

Mysticism is Cognitio Dei experiementalis (the knowledge of God through and from experience). What it meant here is the knowledge of God that, instead of being obtained from instructions, tradition, books, and doctrines, comes from one's own life. In terms of this medieval definition, two possible ways of understanding God may be distinguished. There is the orderly way, dogmatically legitimated and hierarchically directed, and the extraordinary one, resting on experiment and experience, which is incapable of being fully institutionalized. That definition represents a concession of the preecclesiastical and the extraecclesiastical reality of religious experience. (p .45)

Careful analysis of this statement reveals that if this "famous scholastic definition" is appropriate, then mysticism or mystical experience may not necessarily require membership or adherence to an organized institution. One may enter into mystical experience without belonging to any religious body. As a matter of fact, the definition seems to suggest that mysticism is primarily individual, personal and not ecclesiastical or congregational. In other words, the definition seems to hold that an individual's experience and knowledge of the God are more real through a personal search and commitment rather than communal activities such as religious congregational ceremonies and rituals.

Even though this is the ultimate goal (personal knowledge and experience of the God) of most religious groups, the tendency of individuals to know and experience the God "on their own" may, to some extent, contravene or even defy congregational objectives and sustenance.

Such a possible conflict between individual versus congregational goals could be the source of inspiration for some theologians to categorize mysticism as true and false.

Chafer (1976), for instance, as noted earlier, considered the claim of the God's revelation to individuals outside the scriptures as false mysticism. To him, true mysticism should be confined to the unveiling of scriptures to the mind and heart by the Holy Spirit.

If this influential theologian is right, then many mystics may want to sever themselves from ecclesiastical bonds in order to be on their own and attain "supra"-congregational (and, probably, supra-scriptural) dreams.

This would be the case of people like Myss (2007) who suggested that:

Your soul is your connection with eternity, your intermediary between earth and heaven, between your every day physical life and a higher reality. It is your calm eye in the hurricane of a chaotic world yet, it burns to realize its purpose: to communicate with God. It waits impatiently for the opportunity and avenue to unveil self to your own divinity, the God within you. (p. 26)

Of course, such a statement would be classified, according to Chafer's perspective, as false mysticism tends to claim some "realities" that are not necessarily scriptural.

Again the experience of Theresa of Ávila will inconvenience those who hold to Chafer's categories of mysticism. Theresa of Ávila was quoted by Myss (2007) as saying:

I began to think of the soul as if it were a castle made of a single diamond or of very clear crystal, in which there are many rooms, just as in heaven there are many mansions... some above, others below, others at the side; and in the centre and midst of them all is the chiefest mansion where the most secret things pass between God and the souls. (p. 26)

And, as if Myss (2007) was enticing every reader to consider mystical experience as indispensable, she rhetorically asked:

Who would not be seduced by these words? What secrets does God hold for you? If you could find a way into those 
beautiful mansions in your soul where a dialogue between you and God is possible, would you not pursue it? (p. 27)

It is important, at this point, to consider other definitions in order to ascertain the real meaning and the significance of this concept for religious experiences.

The Webster's New World College Dictionary provides a wide spectrum for understanding the current uses of the noun mysticism. It states that mysticism means:

(1) The doctrines or beliefs of mystics; specifically, the doctrine that is possible to achieve communion with God through contemplation;

(2) Any doctrine that asserts the possibility of attaining an intuitive knowledge of spiritual truths through meditation;

(3) Vague, obscure, or confused thinking or belief.

Additionally, Wikipedia defines mysticism as "the pursuit of communion with, identity with, or conscious awareness of an ultimate reality, divinity, spiritual truth, or God through direct experience, intuition, instinct or insight". Mysticism usually centers on a practice or practices intended to nurture those experiences or awareness. Mysticism may be dualistic, maintaining a distinction between the self and the divine, or may be non-dualistic.

Wikipedia also adds that, "Differing religious traditions have described this fundamental mystical experience in different ways" and provides a succinct description for each of the traditions as follows:

(1) Nullification and absorption within God's Infinite Light (Hassidic schools of Judaism);

(2) Complete non-identification with the world (Kaivalva in some schools of Hinduism, including Sankhya ad Yoga, Jhana in Buddhism);

(3) Liberation from the cycles of Karma (Moksha in Jainism and Hinduism, Nirvana in Buddhism);

(4) Deep intrinsic connection to the world (Satori in Mahayana Buddhism, Te in Taoism);

(5) Union with the God (Henosis in Neoplutonism and Theosis in Eastern and Catholic Christianity, Brahma-Prapti or Brahma-Nirvana in Hinduism);

(6) Innate Knowledge (Irfan and fitra in Islam);

(7) Experience of one's true blissful nature (Samadhi Svarupa-Avirbhava in Hinduism and Buddhism).

The description of mystical experience in Christianity (Catholicism) as highlighted above appears to agree with an earlier one by Spencer (1963) who even tended to be more explicit in his comparative study of mysticism in world religions. Spencer held that:

In the religion of the Roman Catholic Church, mysticism holds a recognized though subordinate place. It is commonly acknowledged that the experience of the union with God is the natural outcome of contemplative prayer, which is a prominent feature of the tradition of the catholic piety. In breaking away from the Roman Catholic system, Protestants have to a great extent discarded this practice, and to that extent Protestant religion has cut itself off from the roots of mystical experience. On the other hand, it may be said that mysticism finds a foothold in Protestantism which it does not find in Catholicism, through the emphasis which Evangelical Protestants lay on personal experience. (p. 268)

Underhill (2005), a mystic, put this idea of uniting with the God in more graphic terms, as she stated that:

Mysticism is the science of the ultimates... the science of self-evident reality, which cannot be "reasoned about"; because it is the object of pure reason and perfection. The babe sucking its mother's breast, and the lover returning, after twenty years' separation, to his home and food in the same bosom, are the types and princes of mystics. (p. 9)

She was actually well-known for her outline of, quoted from Wikipedia, "the universal mystic way, the actual process by which the mystic arrives at union with the absolute".

The steps of Underhill's "universal mystic way" will be considered later in this study of mystical 
experience in this paper.

In Christianity, mysticism is perceived differently, depending on doctrinal and dogmatic inclinations of each denomination.

On this note, Paper (2004), in his perspective and the analysis of the mystic experiences, summed up the ways by which the major sections of Christianity relate to mysticism. He said that:

Christianity ranges from mainstream Protestantism, which often considers those who have the experience to be mentally ill unfortunates, to Catholicism, which accepts the experience, but only for a few who are sequestered from the laity, to Orthodoxy, which considers the experience to be the quintessence of the Christian life, to Pentecostalism, which welcomes, even expects, the mystic or other ecstatic experience for full membership. Then there are contemporary developments that fall within the rubric of "New Age", some of which seek to commercialize those with a lifestyle in which individuals with disposable income but limited time hope to find the ultimate in a weekend-another modern concept. (p. 155)

Obviously, all the above definitions so far considered point with the fact mysticism are at the heart of religious pursuits.

Whether mysticism is recommended or required, encouraged or ridiculed by religious groups, it appears that mysticism lies at the root of everyone's desires and endeavors (whether hidden or expressed) - the acquaintance with or, to borrow Underhill's words, "the science of the ultimates".

It is, therefore, important to explore the etymology, practices, and impacts of mysticism in the Christian faith. This is the object of the following section of the paper.

\section{A Brief Historical Development of Mysticism in the Christian Church}

Mysticism in the Christendom, as mentioned earlier in this paper, is obviously a concept that is differently interpreted and therefore differently practiced. The basis for this divergence may be due not only to hermeneutical approaches of different denominations, but also to cultural and philosophical worldviews in various societies.

Johnston (1997) and Hodge (2003) provided a rich historical background of this concept on how it was introduced and practiced in the Christian church over the centuries.

Johnston (1997) traced the origin of mysticism to the Greco-Roman world. Historically, he said:

The word mysticism is associated with the mystery religions or mystery cults which flourished in the Greco-Roman world in the early centuries of the Christian era... The mystic (mustes) was the initiate who in an oath of secrecy swore to be silent or, literally, to keep his mouth shut (muein) about the inner working of his new-found religion. In its original meaning, then, mysticism is associated with mystery and secrecy and the occult. (p. 16)

With regard to the introduction of this concept into Christianity, Johnston (1997) suggested that it came in through the popular ideology known as Platonism. He actually held that, "The word mysticism... passed into Neoplatonism" where:

It meant deliberately shutting the eyes to all external things, a practice which was central to neoplatonic meditation: one excluded the world in order to rise up to the one and be "alone with the alone". The Neoplatonist, Platinus and Procus, use the word muo of the closed eyes of one who is rapt in profound contemplation. While the eyes of the body were closed, the inner eye was open and was searching for wisdom. (p. 16)

Then Johnston concludes saying that the word mystica was introduced into Christianity by an anonymous Syrian monk, a Christian Neoplatonist of the late fifth or early sixth century AD, who composed several theological treatises, one of which was named Mystica Theologica. (pp. 16-17) 
Hodge (2003) also traced the origin of the word to the Greek word " $\mu v \sigma \tau \eta$ ऽ", a noun which refers to the "one initiated into the knowledge of the Greek mysteries, one to whom secret things had been revealed" (p. 61).

In respect to the general use of the word mysticism based on its Greek etymology, Hodge (2003) argued that the word has found its ways into modern times, and that "idea of the infinite, and a running up of all knowledge and all duty to the contemplation and love of Him" have led schools such "the whole Alexandrian school of theology in the early church" to be perceived as mystical (p. 62).

Concerning the sense in which Evangelical Christians are called Mystics, Chafer (1976) held that, “... They are stigmatized as Mystics, by those who discard everything supernatural from Christianity", because they admitted a supernatural influence of the spirit of the God upon the soul, and recognized a higher form of knowledge, holiness, and fellowship with the God, as the effects of the influence... (p. 63).

In the early church, mysticism was evolved from Montanism to New Platonism.

According to Hodge (2003), Montanism arose in the second century with Montanus who "taught that as the ancient prophets predicted the coming of the Messiah through whom new revelations were to be made; so Christ predicted the coming of the Paraclete through whom further communications of the mind of God were to be made to his people" (p. 71). But this idea gradually show its influence on declining in the early 6th century by the emergence of New Platonism which arose from the writings of an unidentified author who was originally thought to be Dionysius the Areopagite, but is now preferably referred to as Pseudo-Dionysius.

"New Platonism", said Hodge (2003), evolved into a doctrine that "quiets the conscience, as it precludes the idea of sin; it gives the peace which flows from fatalism; and it promises the absolute rest of unconsciousness when the individual is absorbed in the bosom of the infinite" ( p. 72).

In the Middle Ages church, "Very different views were entertained of the nature of the "oneness with God", Hodge (2003) referred to three main classifications of thinkers of the time. According to him, "Shedd classified Medieval Mystics into the heretical, the orthodox, and an intermediate class he called latitudinarian. Neudeker", basically in the same way as Shedd did, "talked of Theosophists, Evangelical, and Separatist. Ullmann", on the other hand, perceived the issue of mysticism from the perspective that "Oneness with God was the great end to be desired and pursued, and that union was to be sought, not so much through the truth, or the church, or ordinances, or Christian fellowship; but by introspection, meditation, intuition". But, "from its essential nature”, Hodge (2003) remarked, “... The tendency of mysticism was to pantheism. And accordingly undisguised pantheism was not only taught by some of the most prominent Mystics, but prevailed extensively among the people" (p. 76).

During and after reformation, mysticism was accelerated most especially by Storch and Stübener who, according to Christian Classics Ethereal Library (Retrieved from http://www.ccel.org/ccel/hodge/theology1.iii. iv.iv.html), proclaimed themselves prophets and "denounced learning and church instructions, and taught that all reliance was to be placed on the inward light, or supernatural guidance of the Spirit". Carlstadt was also reported by Christian Classics Ethereal Library to have given those self-proclaimed prophets "his support and exhorted the students to abandon their studies and to betake themselves to manual labor".

Hodge (2003) also notes with emphasis on Schewenkfeld who differed radically from Mystics of his time, most of whom were led into pantheistic doctrines, and "held to a form of dualism" (p. 82).

His writings and those of other mystical writers such as Paracelsus, Weigel, Jacob Boehme, etc., marked the reformation period.

By the end of the 17th century, Hodge (2003, p. 84) continued, "A mystical and spiritual tendency was 
almost as extensively manifested. In Germany, it took the form of mysticism and Pietism; in England, of Quakerism; in France, of Jansenism and mysticism; and in Spain and Italy, of Quietism".

Of course, these forms of mysticisms can be noticed both in their orthodox and heterodox forms in various Christian groups today.

Hodge (2003) ended his discussion on mysticism with a very thought-provoking defense of the Scriptures against mysticism. But, what is more provoking is the way he seemed to place Romanism and mysticism at the two extremes of scriptural misinterpretation. For him,

Romanists, while admitting the infallibility of the Written Word, still contend that it is not sufficient; and holds that God continues in supernatural manner to guide the church by rendering its bishops infallible teachers in all matters pertaining to truth and duty. Mystics, making the same admission as to the infallibility of the Scripture, claim that the Spirit is given to every man as an inward teacher and guide, whose instruction and influence are the highest rule of faith, and sufficient, even without the Scriptures, to secure the salvation of the soul. (p. 98)

Hodge (2003) noted that there is no scriptural foundation, which is contrary to the scriptures and the facts of experience, and that there is no criterion by which to judge the source of inward suggestions.

Hodge's (2003) observations were very significant in the sense that, as far as Christian mysticism is concerned, there can indeed be false and true forms of mysticism.

If he was right in his description of Romanism and mysticism, anyone who is familiar with the biblical principles of the Christian faith will tend to side with him, because these two concepts implicitly deny the Scriptures.

The question, however, rises when one analyzes Hodge's understanding of mysticism in his concluding statement as stated above. He seemed to ignore the fact that some biblical passages actually encourage personal pursuit of the likeness of the divine. Such passages, when properly interpreted and applied, will rather ground the seeker into the Scriptures and guide him or her into proper Christian mystical experience. These passages will be sampled and discussed under the reflection on mysticism in the Seventh-Day Adventist Church at the end of this paper.

Suffice it to say, at this stage, one needs to be careful about the terminologies used to describe various ideologies in connection with mysticism, as Johnston (1997) seemed to suggest that anyone who wants to define mysticism would find himself/herself involved with Zen, challenged by Dr. D. T. Suzuki, poring over books on Yoga, contending with Thomas Melton, Mahatma Gandhi, and the Miharishi Mahesh Yogi. Moreover, Johnston (1997) would have to deal with cosmic consciousness, sudden illumination, the occult, and even witchcraft. He might well throw up agonized hands in despair (p. 15).

The fact that mysticism may refer to many things that are unscriptural, which should not be the basis for branding mysticism as entirely unscriptural. Such a position may rather tend to be unscriptural.

It is crucial to say here that the attempt to brand as unscriptural the pursuit of Godliness or Christlikeness through renouncing the world and renewing of the mind, is factually unscriptural. At the same time, denying the fact of the pursuit of Godliness or Christlikeness through renouncing the world and renewing of the mind (which is achieved through thorough knowledge of the Word of God and personal intentional connection with God) is a form of mysticism, and is equally problematic unless, of course, one provides a specific definition of mysticism to justify one's point of reference.

Ultimately, one may rather be on a safer side by holding that some biblical principles for Christian religious experiences are mystical in nature, but not all forms of mysticism as known today are biblically 
justifiable. And this is one of the reasons why there are different religions and different philosophies of life.

The following section of this paper intends to through more light to the characteristics of mysticism in order to bring out more realities about its presence in the Christian faith.

\section{Characteristics of Mysticism}

According to Wikipedia, we learnt that Underhill had outlined the universal mystic way, which is the actual process by which the mystic arrives at union with the absolute.

According to this encyclopedia, Underhill "identifies five stages of this process". These steps are briefly explained as follows:

First is the awakening, the stage in which one begins to have some consciousness of absolute or divine reality. The second stage is one of purgations, which is characterized by an awareness of one's own imperfections and finiteness. The response in this stage is one of self-discipline and mortification. The third stage, illumination, is marked by a consciousness of a transcendent order, a vision of a new heaven and a new earth. The great mystics go beyond the stage of illumination to a fourth stage... the dark night of the soul. This stage, experienced by the few, is one of the final and complete purifications and is marked by confusion, helplessness, stagnation of the will, and a sense of the withdrawal of the God's presence. It is the period of the final "unselfing" and the surrender to the hidden purposes of the divine will. The final and last stage is one of unions with the object of love, the one reality, the God. Here the self has been permanently established on a transcendental level and liberated for a new purpose. Filled up with the divine will, it immerses itself in the temporal order, the world of appearances in order to incarnate the eternal in time, to become the mediator between humanity and eternity.

Boehme (as cited in Cutsinger, 2003), another well-noted Christian mystic, provided us with an interesting description what takes to embark on a mystical journey. He depicted this through a conversation between a mystic master and his disciple who was struggling in his early stages of the process. The following is an extract of the conversation.

The disciple said to his master, "Sir, how may I come to the supernatural life, so that I may see God and may hear God speaking?" The master answered and said, "Son, when you can throw yourself into that in which no creature dwells, though it be but for a moment, then you shall hear what God says".

Then the disciple, probably more and more interested, probed further saying, "Is that in which no creature dwells near at hand, or it is far off?"

The response of the master reminds us of Theresa of Ávila that were referred to earlier. He told his disciple, "It is in you, my son, if you can for a while but cease from all your own thinking and willing, you shall hear the unspeakable words of God".

On hearing these words from the master, the disciple now seems to rather be perplexed as he enquires, "How can I hear Him speak when I stand still from thinking and willing?"

This question apparently marks a very crucial juncture for the psychology of religious experience, and the reply from the master, at this time, calls for critical examination.

The question is significant for the psychology of religious experience in that the questioner seems not to see anything in which the master can be involved while putting aside his thinking and will. In this respect, psychology may comfortably side with him, as it may reasonably hold that whatever requires our active participation cannot exclude our mind.

Interestingly, the master responded, saying,

When you stand still from the thinking of self and the willing of self, when both your intellect and will are quiet and passive to the impressions of the Eternal Word and Spirit, and when your soul is winged up and above that which is 
temporal, the outward senses and the imagination being locked up by the holy abstraction, then the eternal hearing, seeing, and speaking will be revealed in you. Thus God sees through you, being now an organ of His Spirit, and so God speaks in you, and whispers to your spirit, and your spirit hears his voice. (p. 6)

This reply apparently plunged the disciple into a more perplexing state as his next question implies. He followed up asking, "But with what shall I hear and see God since he is above nature and creature?" At this point, the master begins to reveal the underlying ultimate desire of many a Mystic. He retorted, rather categorically, saying,

Son, when you are quiet and silent, then are you as God was before nature and creature; you are what God was then; you are that with which He made your nature and creature. Then you hear and see even with that with which God Himself saw and heard in you before ever your own willing or your seeing began. (p. 6)

This conversation, though not fully reproduced here, is very inspiring. It discloses to the readers, on the one hand, the apparently indispensable need of mystics to identify themselves with the ultimate, and the necessity of journeying alone, even out of one's mind, on the other hand.

Probably, one more question from the conversation deserves adding, as it underscores the necessity of this personal journey. The disciple, seemingly harboring some sense of failure, asks, "What now hinders or keeps me back so that I cannot come to that with which God is to be seen and heard?" Then the master answered and said,

Nothing truly but your own willing, hearing, and seeing do keep you back from it, and hinder you from coming to this supersensual state. And it is because you strive so against That out of which you yourself are descended and derived that you thus break yourself off, with your own willing, from God's willing, and with your own seeing from God's seeing. (p. 6)

Underhill (2005) perfectly agreed with this master concerning the whole objective of Christian mystics the world over and throughout history. She argued, in reference to mystics, that:

We meet these persons in the East and the West; in ancient, mediaeval, and modern worlds. Their one passion appears to be the prosecution of a certain spiritual and intangible quest: the finding of a "way out" or a "way back" to some desirable state in which alone they can satisfy their craving for absolute truth. This quest, for them, has constituted the whole meaning of life. (p. 1)

Conversely, what most Mystics may consider to be spiritual exercises that lift them from this world to the world of the Ultimate, some psychologists, such as Prince and Savage, related those exercises to regression to infancy. Wulff (1997) quoted these two psychologists' viewpoints as describing mystical experiences as return to infantile state. They claimed to observe in the Mystics:

(1) General abstraction from the external world and unresponsiveness to immediate external stimulation, as observed both in meditating yogis and in infants having highly pleasant or unpleasant experiences;

(2) Vague, distorted, or fragmentary imagery of the type reported by Ramakrishna and thought to be hallucinatory revivals of what the infant experiences while nursing at the breast;

(3) An ecstatic feeling of immediate contact with primal reality;

(4) The experience of fusion with a greater being and a corresponding disappearance of the sense of self;

(5) The incapacity to express these experiences. (p. 365)

However, these observations have been acknowledged by some notable mystics, such as Claire Owens (1965), even though they interpreted them differently. Wulff (1997) quoted Claire Owens's viewpoint as suggesting that: 
Mystical regression, if it be such, is to a collective level that is a resource for transformation in the direction of inner harmony and wholeness. She points out that the mystic's withdrawal from the world is voluntarily chosen as a means of attaining some higher value. Whereas an encounter with the "primal reality" leaves the infant immersed in erotic bodily sensations, the mystic is rendered oblivious to bodily feelings and purified of narcissistic tendencies. (p. 365)

The difficulty in reconciling psychologists' interpretation of mystical experiences with mystics' understanding of their own experiences is probably accentuated by Myss (2007) who, addressing the impediments to mystical attainment, said:

But you have a major obstacle to overcome in order to communicate with God: your reliance on your own mind in matters of spirituality... The mind, however, is useless in finding a way into mystical matters. (p. 27, emphasis mine)

If Myss is right, and she may not be the only mystic to hold on to this claim, then psychology is likely to not offer as much help to mystics and religionists as intended toward the understanding of mystical experience! In other words, if mystical realities occur outside the realms of the mind which is of course the operational domain of psychology, then psychology has very little to offer in this regard.

Surprisingly, Sölle (2001), a mystic, quoted (with apparent approbation) William James' characteristics of the experience of mystical assurance as follows:

(1) The loss of all worry; the sense that all is ultimately well with one; the peace, the harmony and the willingness to be, even though the outer conditions should remain the same;

(2) The sense of perceiving truths not known before that make life's mystery lucid;

(3) The objective change that the world seems to undergo, making it seem "new" and never having been seen that way before;

(4) The ecstasy of happiness. (p. 21)

The questions then arise: Is it possible to conceive of this would-be mystical assurance outside of the mind? Where is the center of "all worry", "peace", "happiness", etc., as acknowledged by Soelle? Could these be outside of the mind?

It seems important to note at this point that, much as psychologists are challenged in their attempt to contribute to the understanding of mystical experiences, mystics also need to take interest in studying their personal biochemical and physiological functioning, lest they mistake ordinary induced mental states for supernatural transcendence!

Similarly, mystics, religionists, as well as psychologists may have to begin developing new hermeneutical tools as mysticism may soon "fade away" as a result of its rising suppression by fast-growing "DNA activation".

A DNA activator, Toby Alexander (2009), for instance, seemed to lament inefficacy of mystical endeavors and the strenuous struggle for mystical experience when he remarked that, "Most people have to meditate for many years just to have a so-called 'mystical' experience, that is how disconnected we are now". Then, he argued for a seemingly "better" and "faster" way of reconnecting by describing the immediate benefits of DNA activation. He asserted that:

DNA activation removes the energetic blockages to you embodying your higher self, Oversoul consciousness, Avatar self, and Rishi - the part of you closest to source or God... DNA activation activates the strands that allow you to travel out into the void and effectively "hand deliver" your desires to the Creator... We are pieces of God who have forgotten who we are, and with the forgetting we forgot how to do it... We are such an aspect or a face of that collective identity that some people choose to call God, or some people choose to call source. 
Obviously, this form of religious experiences is a serious threat to many religious ideologies and practices, including orthodox and heterodox mysticisms.

If some Christians, such as Chafer, are reluctant to acknowledge some forms of mysticism as biblically sound, then the battle against post-modern ecstatic religious experiences, such as DNA activation, will prove almost overwhelming and devastating to their souls!

On this note, a reflection on mysticism and the Seventh-Day Adventist religious experience is worth entertaining.

\section{Mysticism in Conservative Protestant Faiths: The Case of Seventh-Day Adventists}

The Seventh-Day Adventist Church is one of the Christian denominations that are noted for strong claims of Biblical doctrinal purity. As such, one may expect its adherents to stick to all the biblical principles for Christian life.

This means that, for instance, if the Bible teaches some forms mysticism, the Seventh-Day Adventists should strive to experience it to the fullest.

More so, if the perception of the church about mysticism should be that of Protestantism in general (Protestantism, according to Jordan Paper, as noted earlier, often considers those who have the mystical experience to be mentally ill unfortunates), the integrity of the teachings and practices of the church will greatly hang on the presence or the absence of mysticism in the Bible.

As we reflect on the idea of mysticism, the overarching meaning of mysticism will be the pursuit of the Godliness or Christlikeness through renouncing the world and renewing the mind, which is achieved through thorough knowledge of the word of the God and personal intentional connection with the God.

In considering mysticism from the perspective of Bible-abiding church, the two essential questions should reasonably be, does the Bible teach mysticism or recommend mystical experiences? How should mysticism be perceived in the Seventh-Day Adventist church?

To the first question, a reflection on some Bible statements deserves our attention.

For a not-well-Bible-grounded person, mystical feelings may be aroused by many biblical statements, especially in the New Testament.

One of such is Christ's own words in John 15:5, "I am the Vine, you are the branches. He who abides in $\mathrm{Me}$, and I in him, the same brings forth much fruit; for without Me you can do nothing".

These words, among other things, stimulate in the Christian believer, the desire to be connected to his or her Redeemer. And since that Redeemer can neither be seen nor touched physically, the believer is only left with the spiritual means to reach out of himself/herself onto him/her whose presence is the ultimate purpose of discipleship. This stimulation is even more validated in the believer by the very Words of the Redeemer who, while on earth, said, "But seek first the kingdom of God and his righteousness; and all these things shall be added to you" (Matt. 6:33).

In fact, the Christian who is already itching to embrace mysticism can feel prepared to go to any extent of self-denial and seclusion from the world as long as the strict and quite radical requirements of discipleship keep ringing into his or her mind:

If anyone comes to me and does not hate his/her father and mother and wife and children and brothers and sisters, yes, and his own life also, he cannot be My disciple. And whoever does not bear his cross and come after Me, he cannot be My disciple... So then, everyone of you who does not forsake all his possessions, he cannot be My disciple. (Luke 14: 26, 27, 33) 
Additionally, Pau, who was thought by many Bible students to have written more than $50 \%$ of the New Testament, seemed to cry for such a sublime experience that would take him out of himself and lift him to a state of nothingness to self and fullness in Christ which he later seemed to be attaining through self-discipline. Eventually, he appeared to have confidence that he was indeed getting out of himself to dwell into the infinite. In Romans 7: 19-24, he exclaimed:

For I do not do the good that I desire; but the evil which I do not will, that I do. But if I do what I do not desire, it is no more I working it out, but sin dwelling in me. I find then a law: When I will to do the right, evil is present with me. For I delight in the Law of God according to the inward man; but I see another law in my members, warring against the law of my mind, and bringing me into captivity to the law of sin being in my members. O wretched man that I am! Who shall deliver me from the body of this death?

Then, the Christians who are already predisposed to mysticism may hear Paul as giving them an idea of his resolution to reach out of himself and even this world to the Ultimate, Jesus Christ, when he exclaimed:

But whatever things were gain to me, those I counted loss for Christ. But no, rather, I also count all things to be loss for the excellency of the knowledge of Christ Jesus my Lord, for whose sake I have suffered the loss of all things, and count them to be dung, so that I may win Christ and be found in Him; not having my own righteousness, which is of the Law, but through the faith of Christ, the righteousness of God by faith, that I may know Him and the power of His resurrection and the fellowship of His sufferings, being made conformable to His death; if by any means I might attain to the resurrection of the dead. (Phil. 3: 7-11)

Definitely, Christian mystical minds may see Paul as somehow growing in the relationship with God that, at a point in time, sensed the nothingness of self and fullness of God in him, an idea that seems to be implied in his testimony to the Galatians to whom he wrote:

I have been crucified with Christ, and I live; yet no longer I, but Christ lives in me. And that life I now live in the flesh, I live by faith toward the Son of God, who loved me and gave Himself on my behalf. (Gal. 2: 20, emphasis mine)

Those with mystical longings will argue that many influential Bible characters, including Jesus himself, lived mystical lives owing to the fact that the thoughts and lives of these Bible Characters recommended the personal journey toward the ultimate as understood in some definitions and principles of mysticism.

For example, mystics may readily (but wrongly) liken Paul's self-description and struggle for the ultimate to that of the well-known mystical writer and mystic, Rumi Jalal al-Din (2009) whose thoughts are encapsulated in one of his popular mystical poems. Rumi (2009) wrote:

What excuse have you to offer, my heart, for so many shortcomings?

Such constancy on the part of the Beloved, such unfaithfulness on your own!

So much generosity on his side, on yours such niggling contrariness!

So many graces for him, so many faults committed by you!

Such envy, such evil imaginings and dark thought in your heart, such drawing, such tasting, such munificence by him! Why all this tasting?

That your bitter soul may become sweet.

Why all these drawing?

That you may join the company of the saint.

You are fearful at last of your wrongdoings, you seek desperately a way of salvation; in that instant why do you not see by your side him who is putting such fear into your heart? (p. 37)

Many Christians in search for mystical experiences can indeed be led astray by misunderstanding Apostle 
John's striving for Godliness or Christlikeness, which seems to be a condition sine qua none for the kingdom of God, because he declared:

Beloved, now we are children of God, and it has not yet been revealed what we shall be. But we know that when $\mathrm{He}$ shall be revealed, we shall be like Him, for we shall see Him as He is. (1 John 3: 2, emphasis mine)

Definitely, if mystical experience can mean, at least, a deliberate effort to have an intimate connection with God with the ultimate goal of becoming like Him even here on earth (Matt. 5: 48) and when he appears at the end of the world (1John 3:2), many Christians may not feel offended, were they to be referred to as mystic.

Seventh-Day Adventists, however, would still argue that none of the definitions of mysticism as discussed above fit the actual biblical teachings on connecting with the Ultimate reality-God. To buttress this stand of Seventh-Day Adventists, a comparative examination of the common characteristics of the definitions of Christian mysticism in the light of Biblical teachings is very significant. Table 1 considers some popular definitions of mysticism and show from scripture how Christianity cannot safely practice it.

Table 1

Seventh-Day Adventist Possible Responses to Mystical Teachings and Practices in Christianity

\begin{tabular}{|c|c|c|c|c|}
\hline \multicolumn{3}{|c|}{ Christian mysticism } & \multicolumn{2}{|c|}{$\begin{array}{c}\text { Seventh-Day Adventist possible } \\
\text { bible-based arguments }\end{array}$} \\
\hline $\begin{array}{l}\text { Christian } \\
\text { affiliation }\end{array}$ & Sampled key definitions & $\begin{array}{l}\text { Common } \\
\text { characteristics of } \\
\text { the definitions } \\
\end{array}$ & Argument & Biblical support \\
\hline $\begin{array}{l}\text { Medieval } \\
\text { Catholicism } \\
\text { (Soëlle, 2001) }\end{array}$ & $\begin{array}{l}\text { "Cognitio Dei experiementalis" (the knowledge of } \\
\text { God through and from experience). The knowledge } \\
\text { of God that, instead of being obtained from } \\
\text { instructions, tradition, books, and doctrines, comes } \\
\text { from one's own life. }\end{array}$ & \multirow{5}{*}{$\begin{array}{l}\text {-None of the } \\
\text { definitions refers to } \\
\text { the word of God. } \\
\text {-Man is the starting } \\
\text { point and initiator. } \\
\text {-No emphasis on } \\
\text { any belief system. }\end{array}$} & $\begin{array}{l}\text { God is known through } \\
\text { instruction from and } \\
\text { mediation on his } \\
\text { word, imitation of } \\
\text { Christ and fellowship } \\
\text { with other believers. }\end{array}$ & $\begin{array}{l}\text { Deuteronomy 6: } \\
\text { 4-9; Psalm 119: } \\
\text { 105; Psalm 19; } \\
\text { Matthew 2: 29; } \\
\text { John 8: 32; } \\
\text { John 17: } 13\end{array}$ \\
\hline $\begin{array}{l}\text { Protestant } \\
\text { mystical } \\
\text { experience } \\
\text { (Spencer, } \\
\text { 1963) }\end{array}$ & $\begin{array}{l}\text {.. It may be said that mysticism finds a foothold in } \\
\text { Protestantism which it does not find in } \\
\text { Catholicism, through the emphasis which } \\
\text { evangelical protestants lay on personal experience. }\end{array}$ & & $\begin{array}{l}\text { Without faith no } \\
\text { practical relationship } \\
\text { with God is possible. }\end{array}$ & $\begin{array}{l}\text { Hebrews 11: 6; } \\
\text { John 14:1; } \\
\text { Hebrews 10: } 38\end{array}$ \\
\hline $\begin{array}{l}\text { Modern } \\
\text { Catholic } \\
\text { mysticism } \\
\text { (Spencer, } \\
1963 \text { ) }\end{array}$ & $\begin{array}{l}\text { It is commonly acknowledged that the experience } \\
\text { of the union with God is the natural outcome of } \\
\text { contemplative prayer, which is a prominent feature } \\
\text { of the tradition of the catholic piety. }\end{array}$ & & $\begin{array}{l}\text { Christ is the only } \\
\text { mediator for biblical } \\
\text { spirituality that leads } \\
\text { to union with God. }\end{array}$ & $\begin{array}{l}\text { Acts } 4: 12 ; \text { John } \\
14: 6 ; 2 \\
\text { Corinthians } 4: \\
6 ; \text { Hebrews } 4: \\
14-16\end{array}$ \\
\hline $\begin{array}{l}\text { Postmodern, } \\
\text { New Age, } \\
\text { Emergent } \\
\text { Church } \\
\text { mysticism } \\
\text { (Underhill, } \\
\text { 2005) } \\
\end{array}$ & $\begin{array}{l}\text { Mysticism is the science of the ultimates ... the } \\
\text { science of self-evident reality, which cannot be } \\
\text { "reasoned about", because it is the object of pure } \\
\text { reason and perfection. }\end{array}$ & & $\begin{array}{l}\text { Christian spiritual } \\
\text { experience involves } \\
\text { concrete reasoning } \\
\text { about real life } \\
\text { experiences. }\end{array}$ & $\begin{array}{l}\text { Isaiah 1: 18; } \\
\text { Philippians 4: 8; }\end{array}$ \\
\hline $\begin{array}{l}\text { Underhill } \\
\text { (Retrieved } \\
\text { from } \\
\text { http://www.chr } \\
\text { istianmystics.c } \\
\text { om) }\end{array}$ & $\begin{array}{l}\text { Mysticism...is the direct intuition or experience of } \\
\text { God; and a mystic is a person who has, to a greater } \\
\text { or less degree, such a direct experience-one } \\
\text { whose religion and life are centered, not merely on } \\
\text { an accepted belief or practice, but on that which the } \\
\text { person regards as first hand personal knowledge. }\end{array}$ & & $\begin{array}{l}\text { Christian spirituality } \\
\text { is rooted in biblical } \\
\text { doctrines. }\end{array}$ & $\begin{array}{l}2 \text { Timothy } 3: \\
16 ; \quad 1 \text { Timothy } \\
6: 3\end{array}$ \\
\hline
\end{tabular}


Despite its singular stand on mysticism, the Seventh-Day Adventist church has incurred several derogatory labels and attacks to the point of being labeled as a cultic movement. Actually, basing on its roots from the Advent movement and its pioneers, the church is often perceived by some thinkers, as a mystical group or cult mostly based on its claim of "extra-biblical" special revelation.

This is, for instance, the argument of the systematic theologian Chafer (1976) who not only saw Adventism as a form of mysticism but even as a false one. He said:

False mysticism includes all those systems which teach identity between God and human life- Pantheism, Theosophy, and Greek philosophy. In it are included practically all the holiness movements of the day; also Spiritism, Seventh-Day Adventism, New Thought, Christian Science, Sweden borgianism, Mormonism, and Millennial Darwinism. (p. 13)

Chafer (1976), referring to those "cults" listed above, went further to explain that:

In presenting their doctrine of the "inner light", they say that, having the indwelling spirit, the individual Christian is in contact with the same one who inspired and gave the Scriptures and that the spirit is not only able to impart added truth beyond that already given in the Bible, but that he is appointed by Christ to do so according to John 16: 12, 13, "I have yet many things to say to you, but ye cannot bear them now. Howbeit when he, the Spirit of truth, is come, he will guide you into all truth". (p. 13)

The question that may rise from Chafer's statements, especially from the Seventh-Day Adventist's perspective would be whether the doctrines of the Seventh-Day Adventist church are indeed founded on statements such as John 16:12,14. Seventh-Day Adventists may rightly reproach Chafer the inability to trace the Church's roots in the Bible prophecy (particularly in Revelation 14). They may also wish they were acquainted with Ellen White's (1903, p. 125) statements about the relationship between her writings and the Bible, since her ministry seemed to be the only reason why she classified the church among the cults or false mysticisms. Ellen White said, "Little heed is given to the Bible, and the Lord has given a lesser light to lead men and women to the greater light".

Of course, Seventh-Day Adventists and even some other Bible students may rightly wonder whether what Chafer called false mysticism is really mysticism, let alone false mysticism! And they may be right to argue against her definitions of true and false mysticisms because, while the Bible clearly teaches that every new revelation must conform "to the Law and the Prophets" (see Isaiah 8: 20), it does nowhere provide time boundaries for God's revelation.

Notwithstanding, Chafer may not be the only one to view Seventh-Day Adventist church as a cult.

This calls for serious reflection on the part of the church with regard to how she portrays herself or relates to the outside world. Even though the church can legitimately demonstrate its biblical and prophetic justification, there is the need to clearly share with other truth seekers its reason for standing alone in this overwhelming quest for mystical spirituality and experiences. Most importantly, the church should see it as a historic mandate to bring to purely biblical alternative to what the whole religious world is seeking to achieve through mysticism.

As a radical outcome of the protestant reformation, the Seventh-Day Church has inherited from her parentage the tendency to over-emphasize exegesis, rationalization and teaching of the Bible to the detriment of experience and participation in worship. This remains her major characteristic in both teaching and praxis. Therefore, if the church does not endeavor to bring out the practicality of biblical spirituality, even her adherents are at the risk of resorting to mysticism in order to satisfy their spiritual longings. 


\section{Conclusions}

From the literature surveyed in this paper, one may rightly agree with Wulff (1997) who identified mysticism as one of the deliberate facilitations of religious experiences. Wulff (1997, as cited in William Hocking, 1912, p. 403) said that,

Solitude is the essence of mysticism... Spiritual seekers of various traditions commonly retreat to the mountains, the forests, or the desert in order to eliminate all intercourse with other human beings and to reduce distractions of civilization. (p. 76)

If Hocking was right (and he most likely was), then mysticism has been in existence in the various religious groups including Christianity, even before the word "mysticism" itself came into scholastic jargon.

However, Biblical Christianity would find it difficult to accommodate the principles of mysticism as sampled in this paper. Most especially, the ideas that are highlighted by Spencer (1963), Wulff (1997), Underhill (2005) and Myss (2007) as already expressed in this paper. Biblical Christianity can never agree with those forms of mysticism that tend to take man out of his human nature and equate him with his Creator.

Indeed, mystics like Al Hallaj, Meister Eckhart, and Angelus Silesius may be among those whose ideologies have scared many a Christian even to mention the word "mysticism" because of their biblically heretical pronouncements.

In fact, Arsen Darnay reported that these mystics make some claims that defy all the positive aspects of mysticism, as far as Biblical Christianity is concerned. He said that:

The Sufi mystic Al Hallaj (858-922) once said, "I am the Truth". That statement cost him his life. Meister Eckhart... identifies his eye with God's - ambiguously enough, to be sure, to escape drastic censure. Angelus Silesius (1624-1677), another mystic, wrote in a poem: "I know God cannot live one instant without Me: if I should come to naught, needs must He cease to be".

Surely, Biblical Christianity cannot agree with such pantheistic or Panentheistic Mysticism that bypass the Biblically prescribed (see Table 1) ways of communicating with God. But, Mysticism in the sense of the "pursuit of Godliness or Christlikeness through renouncing the world and renewing of the mind, which is achieved through thorough knowledge of the Word of God and personal intentional connection with God", is probably the most dangerous form, as it uses the Biblical language to communicate a non-biblical spiritual exercise. This form of mysticism as the main justification for Christian to engage in mystical exercise refuses to reveal to its adherents that Christian have not been called to renounce he world by leaving it, psycho-spiritually. They are called to be the salt of the world. (Matthew 5: 13). The renewal of the mind is achieved through reading and reflecting on the word of God (Psalm 119: 11) rather than evading the body and mind as suggested by many a mystic, such as Myss (2007, p. 27) who argued that our very mind is the major obstacle we have to overcome before we can communicate with God. Additionally, the Bible does not approve anywhere such lifestyles of isolation and self-inflicted poverty as we find in monasteries.

Yet, mystics teachings and ideologies are found in almost all Christian litanies, liturgies, sermons and songs, and a lot of great figures as those listed on Poetseer Website (Hildegard of Bingen, St Francis of Asissi, Mechthild of Magdeburg, St Thomas of Aquinas, Meister Eckhart, Julian of Norwich, St. Catherine of Siena, Angelus Silesius, St Teresa of Lisieux, Thomas Merton, Mother Teresa, Pope John Paul II) in the Christian history are known for mystical life.

Again, several Christian thinkers are making effort to persuade anti-mystical Christians (such as 
Seventh-Day Adventists) that there is a form of mysticism that is safe and Christian, and that is totally different from non-Christian mysticisms. For example, Charles-André Bernard (1997), in his book La Conscience Mystique (mystical consciousness), attempts to differentiate between what he calls mystique Chrétienne (Christian mysticism) and mystiques non-Chrétienne, arguing that "Christian mysticism is founded on God's presence in History; non-Christian forms of mysticism seek to establish a contact with the ineffable reality that is rather symbolized by myths and even the mystery of Incarnation” (p. 89).

It would be safer for the Christian religion to identify the Biblical worldview in matters of spirituality and bring out practical models for communion with god as he prescribes in his word rather than combining monistic and naturalistic theories with Christian Scriptures. In fact, there is no instruction or practice in the Bible that can safely be referred as mystical in the sense of mystical experiences and practices throughout history.

\section{References}

Bernard, C. A. (1977). La conscience mystique. Studia Missionalia, 26, 87-115.

Chafer, S. L. (1976). Systematic theology (Vols. 1 \& 2). Grand Rapids: Kregel Publications.

Cutsinger, J. S. (2003). Not of this world: A treasury of Christian mysticism. World Wisdom, Inc..

Christian Classics Ethereal Library (n.d.). Mysticism at, and after the reformation. Systematic Theology, 1. Retrieved July 22, 2012, from http://www.ccel.org/ccel/hodge/theology1.iii.iv.iv.html

Darnay, A. (n.d.). Mystical experience: An elaboration. Retrieved August 18, 2009, from http://www.adbzone.wordpress.com Hodge, C. (2003). Systematic theology. Hendrickson Publishers, Inc..

Johnston W. (1997). The inner eye of love: Mysticism and religion. San Francisco: HarperCollins, Inc..

Jordan, P. (2004). The mystic experience: Perspective and comparative analysis. Albany: State University of New York Press. Myss, C. (2007). Entering the castle: Finding the inner path to god and your soul's purpose. New York: Free Press.

Rumi, J. A. D., \& Yarshater, E. (2009). Mystical poems of Rumi. Chicago: The University of Chicago Press.

Soelle, D. (2001). The silent cry: Mysticism and resistance. Minneapolis: Fortress Press.

Spencer, S. (1963). Mysticism in world religion. Harmondsworth: Penguin Books Ltd..

Toby, A. (2009). DNA activation. Retrieved August 18, 2009, from http://www.dnaperfection.com

Underhill, E. (2005). Mysticism. Digireads.com Publishing.

White, E. G. (1903). Colporteur ministry. Hagerstown, Maryland: Review and Herald.

Wulff, D. M. (1997). Psychology of religion: Classic and contemporary (2nd ed.). New York: John Wiley \& Sons, Inc.. 